British Heart Fournal, 1978, 40, 429'

\title{
Lignocaine, a new technique for intravenous administration
}

Sir,

In the above article by R. A. Levy et al. (1977, 39, p. 1026) the dose of lignocaine by infusion is stated to be $20 \mu \mathrm{g} / \mathrm{min}$ for patients between 68 and $90 \mathrm{~kg}$ and $30 \mu \mathrm{g} / \mathrm{min}$ for those over $90 \mathrm{~kg}$. This is a very small dose: the usual dosage would be 20 or $30 \mu \mathrm{g}$ per minute per kg body weight.

J. Col,

Universite Catholique de Louvain, Cliniques Universitaires,

Louvain,

Belgium.
This letter was shown to the authors who reply as follows:

Sir,

A disastrous typographical error occurred; the doses should have been given as $20 \mu \mathrm{g} / \mathrm{kg}$ per min and $30 \mu \mathrm{g} / \mathrm{kg}$ per $\mathrm{min}$.

W. J. Mandel, Cedars-Sinai Medical Center, Los Angeles, California 90048, U.S.A. 